\title{
Pigmented Villonodular Synovitis of the Wrist Simulating Carpal Tunnel Syndrome
}

\author{
Piñeiro SM${ }^{1}$, Cueva $\mathrm{RM}^{1}$, Niebla $\mathrm{LH}^{2}$, Pazos $\mathrm{CP}^{3 *}$, Morera $\mathrm{TM}^{4}$ and \\ Rodríguez $\mathrm{YF}^{5}$ \\ ${ }^{1}$ Department of Orthopedics and Traumatology, Provincial General University Hospital, Cuba \\ ${ }^{2}$ Department of Pathological Anatomy, Provincial General University Hospital, Cuba \\ ${ }^{3}$ Department of Comprehensive General Medicine, Cuba \\ ${ }^{4}$ Department of Internal Medicine, Provincial General University Hospital, Cuba \\ ${ }^{5}$ Resident of Orthopedics and Traumatology, Provincial General University Hospital, Cuba
}

\section{Case Report \\ Volume 5 Issue 1}

Received Date: January 10, 2022

Published Date: January 25, 2022

DOI: $10.23880 /$ aabsc-16000174

*Corresponding author: Claribel Plain Pazos, Degree Specialist in Comprehensive General Medicine, Assistant Professor, Faculty of Medical Sciences of Sagua la Grande, Villa Clara, Cuba, Email: claribelpp@infomed.sld.cu

\section{Abstract}

Diffuse pigmented vellonodular synovitis in the wrist region behaving like a carpal tunnel syndrome is rare. The objective of this article is to present a patient with diffuse pigmented vellonodular synovitis of the right wrist simulating a carpal tunnel syndrome resolved with surgical treatment, obtaining optimal results. The patient began with pain in the area of the right wrist, accompanied by paresthetic sensations as well as a diffuse increase in volume in the distal third of the forearm that increased with work activity. During surgery, diffuse proliferation of the synovium of the sheath of the flexor tendons of the fingers was verified, it was resected and sent to Pathology, diagnosing diffuse pigmented vellonodular synovitis. After surgery, the symptoms disappeared with a very satisfactory evolution.

Keywords: Diffuse Pigmented Villonodular Synovitis; Carpal Tunnel Syndrome

Abbreviations: SVPD: Pigmented Villonodular Synovitis; CTS: Carpal Tunnel Syndrome.

\section{Introduction}

Diffuse pigmented villonodular synovitis (SVPD) described by Jaffe, Lichtenstein and Sutro in 1941 [1]. It is a locally destructive fibrohistiocytic proliferation of the synovium characterized by multiple villis and nodular synovial prominences composed of mononuclear synovial cells mixed with multinucleated giant cells, foam cells, siderophagocytic and inflammatory [2]. In $75 \%$ of cases the condition occurs in the knee joint and the remaining $15 \%$ in decreasing order the hip, ankle, wrist, elbow and shoulder [2-4]. The frequency with which it appears in the wrist is rare and it is not common to present as a cause of carpal tunnel syndrome (CTS). Therefore, the objective of this article is to present a patient with a SVPD of the right wrist simulating a CTS resolved with surgical treatment, obtaining optimal results. Patient presentation A 47-year-old white male patient, a large-sized vehicle driver (harrow) who has had an increase in volume in the volar region of the distal third of the forearm and right wrist for approximately three months, accompanied by pain radiating to the second and third finger and that increases with work activity. APP: compensated HT with treatment. Gout with treatment 


\section{Physical Exam}

Diffuse increase in volume was observed in the volar region of the distal third of the forearm and right wrist (Zone $\mathrm{V}$ of the flexors) painful on palpation and movements of the wrist and fingers (VAS $=3$ ), flexion-extension movements of the hand and fingers, it is not reluctant and it is attached to deep planes.

Tinel test: Positive

Phalen test: Positive at $<15$ seconds

Durkan test: Positive at $<30$ seconds

Hyposesthesia of the first, second, and third fingers of the right hand on needle exploration. Complementary

$\mathrm{Hb}: 150 \mathrm{~g} / \mathrm{l}$

Hto: $50 \mathrm{~mm}$

Leukogram with differential: 9x 103 P: 63 L: 30 M: 3 Eo: 4

Coagulogram:

Platelets. $250000 \times \mathrm{mm} 3$

Uric Acid: $470 \mathrm{mmol} / \mathrm{l}$

Rheumatoid Factor: Negative (-)

LE cells: Negative (-)

Proceed surgical

Previous regional anesthesia of the type (Phleboanalgesia) proceeds to asepsis and antisepsis with Betadine $®$, field cloths are placed, incision is made for carpal tunnel lesions (Figure 1), it is decolated by planes reaching the sheath of the Flexor tendons of the fingers (Zone V), of the palmar major, minor and superficial flexor respectively, finding a diffuse thickening of the synovial membrane with a yellow-gray color that progresses towards the carpal tunnel and (Zone III) of the flexors, the transverse ligament is opened and it is advanced towards the palm of the hand, the entire synovial membrane of the walls of the tendon sheaths and of that which was attached to the flexor tendons, palmar major and minor, transverse carpal ligament is decolated, thenar region and sheath of the flexors of the fingers, (Zones III, IV and V) Figure 2.

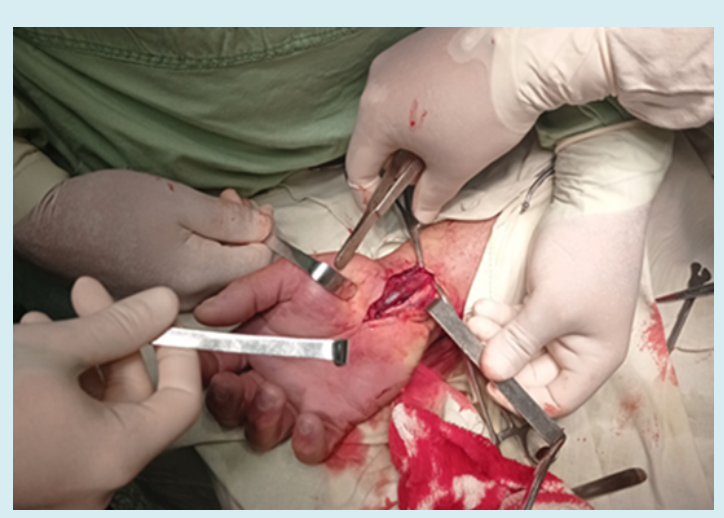

Figure 1: Surgical incision, slightly wider than normal, showing hypertrophy and coloration of the synovium.

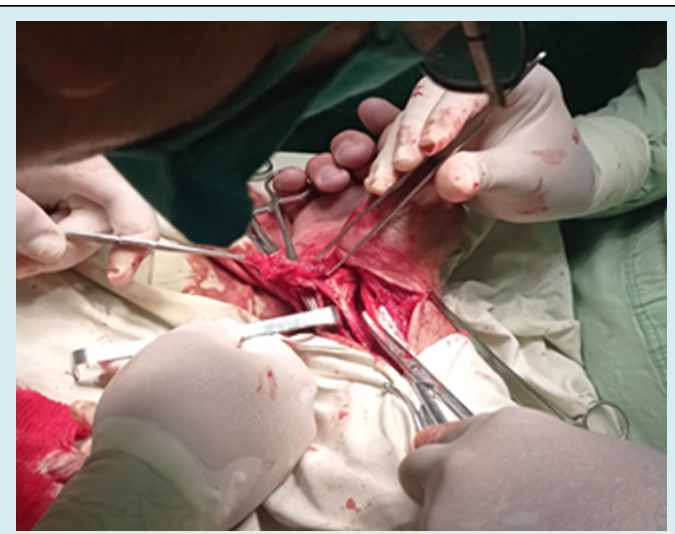

Figure 2: Observe how the synovium enters the carpal tunnel that is already open.

Haemostasis is performed with an electrocoagulator and closure by planes and a compression bandage. Samples were sent to the Department of Pathology whose diagnostic result was Diffuse Pigmented Vellonodular Synovitis (SVPD) (Figure 3).

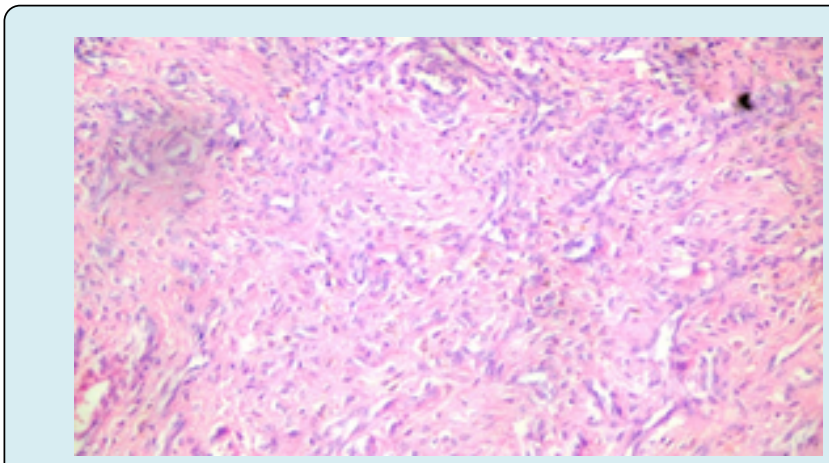

Figure 3: Observe pseudoglandular or alveolar spaces or clefts lined by synovial cells in a stroma composed of histiocytic cells, some of them with the presence of hemosiderin. HE stain x 10 .

As soon as he recovered from anesthesia, the patient reported regression of the paresthesia of the second and third fingers, and once the surgical wound had healed at 10 days, a new evaluation was found to be absent of all pain (VAS $=0$ ) When mobilizing the wrist and the fingers. 30 days after the surgical intervention, he received a medical discharge free of all symptoms, joining his usual work.

\section{Discussion}

Carpal Tunnel Syndrome (CTS) is a commonly diagnosed compression neuropathy in the upper limb characterized by entrapment of the median nerve at the wrist [5-7]. According to Kerwin [8] and described by Campbell's [9] there are several causes of STC (Table 1). 


\begin{tabular}{|c|}
\hline Anatomy of carpal tunnel measurement \\
\hline $\begin{array}{l}\text { Carpal bone abnormalities. } \\
\text { Acromegaly. } \\
\text { Flexion or extension of the wrist. }\end{array}$ \\
\hline Increase in channel content. \\
\hline $\begin{array}{l}\text { Fractures of the wrist and forearm (Colles' and scaphoid } \\
\text { fractures) }\end{array}$ \\
\hline $\begin{array}{l}\text { Dislocation and subluxation (rotational subluxation of the } \\
\text { scaphoid, volar dislocation of the lunate) }\end{array}$ \\
\hline Post-traumatic arthritis (Osteophytes) \\
\hline Musculoskeletal variants. \\
\hline $\begin{array}{c}\text { Aberrant muscles (lumbrical, palmaris longus, palmaris } \\
\text { profundus) }\end{array}$ \\
\hline $\begin{array}{c}\text { Local tumors (neuroma, lipoma, multiple myeloma, cysts, } \\
\text { ganglions) }\end{array}$ \\
\hline Persistent medial artery (obvious or thrombosed) \\
\hline Hypertrophic synovium. \\
\hline Hematoma (Hemophilia, anticoagulant therapy, trauma) \\
\hline Physiology. Neuropathic condition \\
\hline Mellitus diabetes \\
\hline Alcoholism \\
\hline Crush syndrome \\
\hline Exposure to industrial solvents \\
\hline Inflammatory condition \\
\hline Rheumatoid arthritis \\
\hline Gout \\
\hline Non-specific tenosynovitis \\
\hline Infection \\
\hline Fluid balance disturbances \\
\hline Pregnancy \\
\hline Menopause \\
\hline Eclampsia \\
\hline Thyroid disorders (especially hypothyroidism) \\
\hline Renal insufficiency \\
\hline Long time on hemodialysis \\
\hline Raynaud's disease \\
\hline Obesity \\
\hline Lupus erythematosus \\
\hline Scleroderma \\
\hline Amyloidosis \\
\hline Paget's disease \\
\hline External forces \\
\hline $\begin{array}{c}\text { Vibration } \\
\text { Direct pressure }\end{array}$ \\
\hline
\end{tabular}

Table 1: Causes of CTS $[8,9]$.

Among the causes is Gout that this patient suffers from, he undergoes permanent treatment for it and in the complementary ones carried out it was observed that the uric acid value was elevated, thus he was taken to the operating room with the presumptive diagnosis of Gout CTS. In the surgical act, the synovium was not impregnated by the characteristic urate crystals that are easily detached when scraping the synovium with the palpator when observed on macroscopic examination of this structure as described by González Griego [10], but rather it was impregnated with a greyish yellow color with accumulations of hemosiderin running through the tendon sheath and flexor tendons of the wrist and fingers in zone $\mathrm{V}$, the carpal tunnel itself (zone IV) and extended towards zone III of the flexors of the first finger. During the operative act, all synovial membranes that suggested being ill were removed and sent to the Pathological Anatomy Department, which was the one that reported the definitive diagnosis, one year after the operation the patient is free of all ailments and there is no recurrence of the disease.

SVPD does not appear as a cause in the Kerwin and Campbell's table $[8,9]$ so it could be located between the hypertrophic synovitis that produce CTS, the truth is that the possibility of SVPD must be taken into account in cases like this, since there are several although scarce bibliographic reports in this regard [7,11-13].

\section{Conclusion}

SVPD should be taken into account as a possible cause of CTS and the definitive diagnosis should be histopathological, obtaining good results with wide resection of the synovium.

\section{References}

1. Jaffe HL, Lichtenstein L, Sutro CJ (1941) Pigmented villonodular synovitis, bursitis and tenosynovitis. Arch Pathol Lab Med 31: 731-765.

2. Greenspan A, Grainger AJ (2018) Articular abnormalities that may mimic arthritis. J Ultrason 18(74): 212-223.

3. Bravo SM, Winalski CS, Weissman BN (1996) Pigmented villonodular synovitis. Radiol Clin North Am 34(2): 311326.

4. Cotten A, Flipo RM, Chastanet P, Desvigne Noulet MC, Duquesnoy B, et al. (1995) Pigmented villonodular synovitis of the hip: review of radiographic features in 58 patients. Skeletal Radiol 24(1): 1-6.

5. Farhat A, Mughal SM (2021) Is There a Role of Cupping Therapy in the Treatment of Carpal Tunnel Syndrome in Primary Care Setting?. Cureus 13(1): e12954.

6. Khaleel K, Razzak A, Kofahi RM (2020) Carpel tunnel syndrome: A link with vitamin D and calcium. Biomed Rep 13(3): 15. 
7. Wright AR, Atkinson RE (2019) Carpal Tunnel Syndrome: An Update for the Primary Care. Hawai'I J Health Soc Welf 78(11): 6-10.

8. Kerwin G, Williams CS, Seiler JG (1996) The pathophysiology of carpal tunnel syndrome. Hand Clin 12(2): 243-251.

9. Calandrucio JH (2013) Carpal tunnel syndrome, and stenosing tenosynovitis. In: Canale ST, Beaty JH (Eds.), Campbell's, Operative Orthopaedics, Phyladelphia Elseiver-Mosby pp: 3637- 3661.

10. González Griego J (1991) Afecciones de la membrana sinovial. In: González Griego (Eds.), J Artroscopia de la rodilla. Experiencia de un reumatólogo. La Habana: ECIMED pp: 129-150.

11. Schnetzler KA (2008) Acute carpal tunnel syndrome. J Am Acad Orthop Surg 16(5): 276-282.

12. Luo D, Yu L, Yang L, Zhu Q, Ren H, et al. (2021) Atypical and bilateral pigmented villonodular synovitis of wrist in an adolescent patient: case report and literature review. Int J Clin Exp Pathol 14(3): 383-388.

13. Hoeffel JC, Mainard L, Champigneulle J, Claudon M (1997) Pigmented villonodular synovitis of the wrist in childhood. Clin Pediatr (Phila) 36(7): 423-426. 